\title{
Training school teachers to the use of ICT - a preliminary study on motivation and attitude to innovation
}

\section{Mura, Giulia ${ }^{a}$ Ferrari, Mirella $^{\mathrm{b}}$ and Diamantini, Davide ${ }^{\mathrm{c}}$}

${ }^{\mathrm{a} C}$ Centro Quasi, University of Milano, Bicocca, Italy, ${ }^{\mathrm{b}}$ Department of Education, University of Milano, Bicocca, Italy, ${ }^{\mathrm{C}}$ Centro Quasi, University of Milano, Bicocca, Italy.

\begin{abstract}
As part of an innovation project for the public schools of an Italian municipality, the whole body of teachers was enrolled in a training course on the use of ICT in didactic. Before the training, data on ICT expertise, attitude towards teaching and attitude towards training on the use of ICT were collected, to identify factors facilitating and preventing a successful exit of the training, in order to better customize it.

A total of 456 questionnaires were analyzed. The interviewed showed an average level of ICT competence, but relevant gaps on some useful teaching tool. Teachers expressed a good inclination towards the more creative aspects of their profession, an element evaluated as congruent with the adoption of more student-centered pedagogical practice, but conflicting attitudes were expressed on the whole idea of entering a training process.

Results suggest that an effective training program needs to address the change of pedagogical approach adopted from the teachers, the use of online communication tools and spaces as well as educational apps and tool and the reinforcement of a virtuous circle of feedback reception from the students that contribute to motivate the teachers actively involved in the process of change.
\end{abstract}

Keywords: ICT for learning; teacher's training; training planning, motivation. 


\section{Introduction}

The introduction of the ICT in the educational system is quite recent, with the first experiences generally taking place in the Eighties (White 2008).

The first investigations evaluating the impact of the ICT introduction into the educational system have given mixed results: the outcomes are unclear, contradictory, quite often a major investment in technology innovation is followed by minor changes in the didactic and underuse of its potentials. Research found that the use of ICT is often sporadic and superficial, tending more toward reinforcement of traditional practice than enablement of curricular transformation (Eteokleous, 2008; Lai and Pratt 2008).

Other studies (Livigstone 2012, Vanderline and van Braak, 2010) have highlighted the lack of comparable data and validated scales in the description of innovative projects outcomes, an issue that makes it all the more harder to effectively analyze the reasons of success (and of failure). In her review of the difficult relationship between ICT innovation and classroom practice, Livingstone provides possible explanations. On one hand there is a lack of convincing evidence of improved learning outcomes, which may provide stimulus to a quicker, more effective change. Moreover, it is suggested that this difficulty in establishing traditional benefits, combined with "the uncertainty over pursuing alternative benefits, raises fundamental questions over whether society really desires a transformed, technologically-mediated relation between teacher and learner", and point out how the debate "over whether ICT should be conceived of as supporting delivery of a traditional or a radically different vision of pedagogy based on soft skills and new digital literacies" is still open.

A common reflection stemming from different research results in the field of ICT use for educational purpose point out that the integration of computer technology is a complex concern that requires sensitivity to individual and contextual variables (Mueller, Wood, 2012). Consistently, investigations have looked into teachers related variables (Ranjit Singh, T. K., \& Muniandi, 2012) and role played by school principals (Polizzi 2011), but also into dimensions such as the design and implementation of ICT in educational settings; the evaluation of its impact; the scaling up of these kinds of innovations; and the costeffectiveness of technology-enhanced learning environments (Rodriguez et al. 2012).

The first, more relevant reflection arising from these studies is that all the components of the educational system should be involved in the process of change in order to achieve success.

Among the other factors influencing the fruitful integration of ICT in education we found, for example, the attitude towards the use of ICT in education (Player-Koro, 2012), the 
teachers' level of confidence in ICT use, the amount of technical support and of training that combines ICT and pedagogical aspects (BECTA, 2004).

It is then important to reflect upon how these variables are represented among the teachers, and how they can be used to improve the training on the use of ICT in order to maximize the changes that should follow. What is, among the teachers, the disposition to a deep change in their didactic? How much are they willing to invest in their training, what do they expect to achieve and what they value most about ICT? What are the aspects of their profession that they value as more relevant and how this impact on their attitude to training and ICT?

\section{The research}

\subsection{Aim of the research}

The investigation carried out intended to detect the attitudes towards the integration of ICT in the classroom among a group of middle school teachers involved in an extensive program of training and innovation of their school technological infrastructure. Considering the relevance that meta-cognition (Phelps, Graham, 2008) assume when the ICT enter the classroom, it seems extremely important to understand the vision that the teachers are adopting towards these new tools in order to improve their integration. Our initial interest stems from the consideration that such integration is quite often difficult, and that the attitude of teachers plays a key role in the final outcome of any innovation program (Diamantini 2014). The final scope of the research is to gain an accurate description of the representations of a group of teachers training in the use of ICT, and consequently provide suggestion on how such training could be improved.

\subsection{The questionnaire}

To collect the information a questionnaire of 26 items was created. The questions (single choice, multiple choice and Likert scales) included in this analysis investigated the following areas:

- ICT skills (13 items detecting the auto evaluation of ICT expertise and the specific uses of ICT among the respondents).

- Attitudes to teaching (2 items detecting what motivate the respondents in their work experience).

- Attitudes towards training and didactic use of ICT (11 items investigating preferences and representations of ICT and training) 
The questionnaire was submitted at the beginning of a training program on ICT, which was organized by the schools where the teachers worked as part of a wider project of innovation that included as well a massive renovation of the technological infrastructures.

\subsection{The sample}

The sample includes 456 teachers, mainly women (87,5\% women; 8,1\% man, 4,4\% not answered) between 22 and 66 years old (average age: 49 years). They are mainly primary school teachers $(54,8 \%)$, but there is a group of middle school teachers $(28,5 \%)$, and a smaller group of kindergarten teachers $(16,4 \%)$. In average, teachers have been employed for 24 years. The $60,9 \%$ of them teach human science subjects, while 37,5\% teach scientific subjects.

\section{Main results}

\subsection{ICT skills}

The sample show a good level of familiarity with the information technology, and the correlation between their auto-evaluation and the scale of ICT use (number of ICT function used by the respondents) is quite high (Kendall's tau $b=, 458 ; \mathrm{p}<, 001$ ). While the more basic functions, such as the search for information (especially for school) and Office tools are used by the vast majority of the sample, activities such as buying things online or participating to online forums, groups or discussions are far less common. Also the communication via SNS and chats is not very diffused.

Table 1. Online/offline activities of the respondents.

\begin{tabular}{ccc|ccc}
\hline Activity & $\mathbf{N}$ & $\mathbf{\%}$ & Activity & $\mathbf{N}$ & $\%$ \\
\hline Email at home & 417 & 91,4 & Chat & 160 & 35,1 \\
Email at school & 120 & 26,3 & Facebook & 194 & 42,5 \\
Internet at home & 416 & 91,2 & Online game/leisure activities & 98 & 21,5 \\
Internet at school & 155 & 34 & Home banking & 194 & 42,5 \\
School projects & 303 & 66,4 & E-commerce & 166 & 36,4 \\
One own training & 300 & 65,8 & E-governance & 180 & 39,5 \\
Research for school & 420 & 92,1 & Word & 438 & 96,1 \\
Research for personal interests & 382 & 83,8 & Excel & 247 & 54,2 \\
News & 317 & 69,5 & Power Point & 282 & 61,8 \\
Online discussion/forum & 99 & 21,7 & Photoshop & 102 & 22,4 \\
\hline
\end{tabular}


Almost half of the sample has already used technology in the classroom (49,8\%), mainly to show already prepared contents (cd's that come with the text book have been used by $58,3 \%$ of the sample, Lim's by the $40,6 \%$, mobile devices by the $38,2 \%$ and software for the creation of texts or presentations by the 35,5\%). The use of ICT in the classroom positively correlate with the previous participation to training sessions on the same topic $(\mathrm{Phi}=, 257 ; \mathrm{p}<, 001)$. Moreover, having attended training positively correlate with the use of more creative tools, while does not impact the use of CD-ROMs.

Table 2. Correlation between previous training in the didactic use of ICT and use of ICT in the classroom

\begin{tabular}{lcc}
\hline & & $\boldsymbol{\Phi}(\mathbf{p})$ \\
\hline Previous training in didactic use of ICT & Use of ICT with the students & .257 \\
& Software for creation of text and & $.000)$ \\
presentation & $(.000)$ \\
& LIM & .237 \\
& CD rom & Not sig. \\
& Mobile devices & Not sig. \\
\hline
\end{tabular}

\subsection{Attitude to teaching}

Respondents were attracted to the teaching profession because it gives them the possibility to relate to others, especially young people $(78,9 \%)$ and the opportunity of study and constantly improve their knowledge $(41,7 \%)$, while $23,7 \%$ choose the job for the gratification it would give them and $11.2 \%$ appreciate especially the possibility of autonomy in the management of the free time. Accordingly, the most relevant aspects of the profession are the emotional-relational $(69,8 \%)$ and the creative one $(69,5 \%)$, while autonomy is chosen by the $22,4 \%$, social recognition by the $6 \%$ and career by the $1,6 \%$ of the respondents.

\subsection{Attitudes towards training and didactic use of ICT}

While the majority of respondents would like to be updated on the use of ICT $(87,9 \%)$, the time they think should be dedicated to this activity is more varied: about half of the sample would like to dedicate between 17 and 40 hour to the training in the didactic use of ICT in the following year, while $38,9 \%$ think that 16 or less hours would be enough, $8,6 \%$ would 
like to spend more than 40 hours and 1,9\% more than 100 hours to it. As for the preferred training modalities, "frontal" lecture is still the favorite one $(50,2 \%)$, but is closely followed by experiential laboratories $(47,4 \%)$, while less popular methods are blended classes $(24,3 \%)$, interactive workshops $(18,2 \%)$, events $(14 \%)$, and seminar $(11,6 \%)$. When asked about how the training they were about to start would impact their job, $68,4 \%$ said they would probably change their way of teaching, and of these, $1 \%$ scarcely, $26,3 \%$ a little, $62,2 \%$ enough, 5,1\% completely. The knowledge acquire during the training is believed to help: create more personalized tasks for the students $67,6 \%$, involve more the students $61,2 \%$, improve creativity $57,4 \%$, stimulate self-teaching in the students $49,4 \%$, stimulate less consistent students $45,2 \%$, promote group work $44,2 \%$, transmit educational aims $37,8 \%$, improve the students' self-confidence $31,4 \%$, clarify the topics $29,8 \%$, evaluate the student's preparation in a more detached way $3,5 \%$.

\section{Discussion and Conclusion}

Although the general level of ICT skills of the sample is quite good, it seems relevant to focus the attention on some of the less diffused ones, such as the use of spaces of online sharing and communication. These kinds of tools appear to be particularly useful both to connect with the youngest and to carry out innovative teaching projects (Ray, Jackson, Cupaiuolo, 2013). The lack of familiarity with online chats, social networks, blogs and forum suggests the need for a specific training that will improve the skills of teachers in the use of the internet to chat, share ideas and build a discourse.

For the same reasons the training should focus also on the use of tools and apps that can be useful in the implementation of innovative school projects, such as video and image shooting and editing (Godwin-Jones, 2011)

The sample expresses a strong inclination towards the emotional-relational and creative aspects of their profession. Their relationship with the students matters, and so does the possibility to promote an active, creative environment for them. The introduction of the ICT, when accompanied by coherent changes in the didactic, has been proved to augment involvement and satisfaction of the students, (Ferotti 2011), as well as their creativity (Ardizzone, Rivoltella 2008). These effects reinforce the perception of satisfaction and selfefficacy of the teachers, supporting therefore the motivation to change (Moè, Pazzaglia, Friso 2010), once that the initial effort is done.

But it's on the first, initial step that we observe some incongruence in the answers of the sample, which could lead to some problems in the implementation of a process of real change. Many of the interviewed intend to allot scarce time to the training in the use of ICT, insufficient to achieve the effects desired, especially when considering the general 
level of ICT skills. The high level of preference for a traditional training modality such as the frontal lesson, highlight a strong attachment to old pedagogical strategies, that do not suite well both to the contents of the training and the declared intentions of application of the knowledge acquired.

When planning a training program, innovation of the pedagogical approaches should be object of specific attention, as this aspect represents the stumbling block for many teachers, but can be the key to a successful integration of ICT in the classroom.

Summarizing the suggestions emerging by this research, we can conclude that an effective training on the introduction of ICT in education needs to tackle the pedagogical issues connected with the adoption of a more student centered approach; have a strong focus on the use of online communication tools as well as educational apps and tools; support the beginning of a virtuous circle of feedback reception from the students, as a strong motivational tool for the teachers actively involved in the process of change.

\section{References}

Ardizzone, P., Rivoltella P.C., (2008). Media e tecnologie per la didattica, Vita\&Pensiero, Milano.

British Educational Communications and Technology Agency [BECTA] (2013). A review of the research literature on barriers to the uptake of ICT by teachers. Available at http://dera.ioe.ac.uk/1603/1/becta_2004_barrierstouptake_litrev.pdf

Diamantini, D. (2014). Come digitalizzare una scuola. Guerini e Associati, Milano.

Eteokleous, N. (2008). Evaluating computer technology integration in a centralized school system. Computers \& Education, 51(2), 669-686.

Ferotti C. (2011). Didattica personalizzata. Analisi di pratiche e formazione degli insegnanti, Armando Editore, Roma.

Godwin-Jones, R. (2011). Emerging Technologies. Mobile apps for language learning. Language Learning \& Technology, 15(2), 2-11.

Lai, K., Pratt, K. (2008). Positive to a degree: The effects of ICT use in New Zealand secondary schools. Computers in the Schools, 24, 95-109.

Livingstone, S., (2012), Critical reflections on the benefits of ICT in education. Oxford Review of Education, 38(1), 9-24. Available at http://www.tandfonline.com/doi/pdf/10.1080/03054985.2011.577938

Moè A., Pazzaglia F., Friso G., (2010). MESI, Motivazioni, Emozioni, Strategie e Insegnamento. Questionari metacognitivi per insegnanti, Erickson, Trento.

Mueller, J., Wood, E. (2012). Patterns of beliefs, attitudes, and characteristics of teachers that influence computer integration. Education Research International, Article ID $697357,13 \mathrm{pp}$. 
Phelps, R., \& Graham, A. (2008). Developing technology together, together: A wholeschool metacognitive approach to ICT teacher professional development. Journal of Computing in Teacher Education, 24(4), 125-134.

Player-Koro, C. (2012). Factors Influencing Teachers' Use of ICT in Education. Education Inquiry, 3(1), 93 - 108.

Polizzi, G. (2011). Measuring School Principals' Support for ICT Integration in Palermo, Italy. Journal of Media Literacy Education, 3(2), Article 6. Available at: http://digitalcommons.uri.edu/jmle/vol3/iss2/6

Ranjit Singh, T. K., Muniandi, K. (2012). Factors affecting school administrators' choices in adopting ICT tools in schools - The case of Malaysian schools. International Education Studies, 5(4), 21 - 30. DOI: 10.5539/ies.v5n4p21

Ray, B., Jackson, S., Cupaiulo, C. (2013). Building a new system of learning. MacArthur Foundation, Digital Media \&Learning series, Chicago.

Rodríguez, P., Nussbaum, M., Dombrovskaia, L. (2012). Evolutionary development: A model for the design, implementation, and evaluation of ICT for education programmes. Journal of Computer Assisted Learning, 28(2), 81-98. doi: 10.1111/j.13652729.2011.00419.x

Vanderline, R., van Braak, J. (2010). The e-capacity of primary schools: Development of a conceptual model and scale construction from a school improvement perspective. Computers \& Education, 55(2), 541-553. doi:10.1016/j.compedu.2010.02.016

White, G. (2008). ICT Trends in Education, available at http://research.acer.edu.au/digital_learning/2. 